\title{
A prototypal test using stated preferences data to model evacuation decisions
}

\author{
F. Russo \& G. Chilà \\ Dipartimento di Ingegneria dell'Informazione delle Infrastrutture e \\ dell'Energia Sostenibile, DIIES, Università degli Studi Mediterranea di \\ Reggio Calabria, Italy
}

\begin{abstract}
An experiment carried out on stated preferences (SP) data highlights the role of the informer in the user choice process during evacuation conditions. Starting from the SP data, in this paper we propose a prototypal experimentation of choice models simulating the choice to evacuate or not in different evacuation conditions: calibrated models focus on the role of the informer that determine different responses of users, given a particular kind of dangerous event.

Keywords: evacuation conditions, hypothetical scenarios, calibrated parameters.
\end{abstract}

\section{Introduction}

The simulation of user behaviour during an evacuation is a very complex problem, as the behaviour depends on different factors, such as kind and entity of the dangerous event, the socio-economic characteristics of users, and panic. Different demand models have to be specified in relation to the kind of event, which can be classified according to its effects in the space and in the time [1, 2]. With respect to the effect in time, in demand analysis we consider a delayed or immediate approach, in relation to the time gap available between the time at which the dangerous event actually occurs and the time when the event starts its effects on the population.

The international literature relating to evacuation conditions proposes many studies which focus on the hurricane emergency case, by estimating demand models based on revealed preference (RP) surveys. These are inferred from observations of the decision maker's actual choices, in relation to real contexts [3-5]. As RP data are not available for all dangerous events, such models cannot 
be directly applied to other dangerous events [1, 6]. The prediction of user behaviour becomes essential. For this purpose, evacuation trials and stated preference (SP) surveys may be conducted.

To approach this problem, in previous works we introduce hypothetical scenarios to analyze, in the absence of evacuation trials, the statistical behavioural of the users in evacuation conditions from their statements (SP data) [7].

Obtained results have pointed out the importance of the informer in determining the different responses of users, given a particular kind of dangerous event $[8,9]$. The knowledge of the figures that have the better credibility, allow the possibility of organizing an emergency plan with activities adequate to perform clear outcomes and then goals $[10,11]$. In order to plan activities, it is necessary to start from a specific demand-supply interaction model [12], introducing the dynamic in terms of qualifying elements $[13,14]$.

In this work we should propose choice models in considering, for evacuation conditions, the role of the informer in the user choice process.

Below we describe hypothetical scenarios proposed for the sample considered (section 2) and proposed models based on analysis of statements (section 3); we then draw some prototypal conclusions (section 4).

\section{Database}

In this section we propose a description of data used in the model calibration.

Data are obtained from hypothetical scenarios proposed in an experiment conducted at Mediterranea University of Reggio Calabria, during a planning transport seminar at LAST (Laboratory of Transport System Analysis), which took place in 2011. The experiment was developed as described below. The analyst read aloud the description of hypothetical emergency scenarios, one scenario at a time. Each user in the sample then had to fill out a paper ballot with all information relating to a choice context (traditional method), choosing from a range of alternative options, as in the choice method of SP surveys. by:

Emergency scenarios proposed to the participants (table 1) are characterized

- an anthropogenic kind of dangerous event;

- delayed effect in the time of the dangerous event;

- absence of constrained times to evacuate;

and they are different in respect of:

- effect in the space, which could be punctiform, for scenario 1 , or diffused, for scenario 2;

- place of effect for users during the dangerous event, which could be the user's workplace, for scenario 1 , or downtown, for scenario 2 .

In particular, in scenario 1 we analyze the different responses of users in respect of the informer who communicates the state of emergency to potential stakeholders: a stranger or the head of department. The objective is to determine whether, according to the reliability of the informer who broke the news, different behaviour may be found in users. 
Scenario 2 was constructed by considering an environment different from the workplace, within the university campus: the environment is the city centre, and the objective is to test any differences in behaviour under more critical traffic conditions, in an urban rather than a campus context. Also in this scenario, we test differences in respect of the considered informer: a stranger, a representative of the Mayor or a professor.

Table 1: $\quad$ Scenarios description for dangerous events with delayed effect in the time.

\begin{tabular}{|c|c|c|c|c|}
\hline \multicolumn{2}{|c|}{ Scenario } & \multirow{2}{*}{$\begin{array}{c}\begin{array}{c}\text { Effect in } \\
\text { the space }\end{array} \\
\text { Punctiform }\end{array}$} & \multirow{2}{*}{$\begin{array}{c}\begin{array}{c}\text { Place of effect } \\
\text { for user }\end{array} \\
\text { Workplace }\end{array}$} & \multirow{2}{*}{$\begin{array}{l}\text { Informer } \\
\text { Stranger } \\
\text { Department } \\
\text { head }\end{array}$} \\
\hline 1 & $\begin{array}{l}\text { You are working at the LAST laboratory of the } \\
\text { University of Reggio Calabria on a report to be } \\
\text { delivered shortly. Suppose an informer suddenly } \\
\text { enters your room and asks you to leave your } \\
\text { workplace because a bomb is going to explode in the } \\
\text { laboratory. The informer tells you to go and reach } \\
\text { Piazza San Brunello. The informer suggests that, to } \\
\text { allow faster flow, he/she will open the locked gate to } \\
\text { the Agricultural College of the University of Reggio } \\
\text { Calabria. }\end{array}$ & & & \\
\hline 2 & $\begin{array}{l}\text { You are in the town hall, in the Hall of Lamps, for a } \\
\text { conference on the Euro-Mediterranean area. You } \\
\text { have arrived at around 9.20, after parking your car on } \\
\text { Via Marina at the Villa Zerbi. Suddenly, an informer } \\
\text { breaks into the hall and tells you that you must } \\
\text { evacuate the building: a tanker full of flammable } \\
\text { liquid is blocked between Via Marina and Corso } \\
\text { Garibaldi and is about to explode. }\end{array}$ & Diffused & Downtown & $\begin{array}{l}\text { Stranger } \\
\text { Representative } \\
\text { of the Mayor } \\
\text { Professor }\end{array}$ \\
\hline
\end{tabular}

In scenario 1 we consider the effect of two different informers (stranger or department head) when the dangerous event is with punctiform effects in the space and the user is in her/his workplace.

In scenario 2 we consider three different informers (stranger, representative of the Mayor, professor) when the dangerous event is with diffuse effects in the space and the user is downtown. We focus on a different place of the user, in order to assess whether and how this can affect the behaviour found in the workplace.

We consider three prototypal samples:

- Sample A, a focus group of 25 people, aged between 23 and 54 years, characterized by a high cultural level (e.g. professor, researcher, $\mathrm{PhD}$ student), useful for testing SP surveys, identifying significant variables not yet included in the survey;

- Sample B, including 51 people, aged between 20 and 31 years, participating in a transport seminar at LAST [9];

- Joint sample A+B, including 76 people, aged between 20 and 54 years.

In tables 2 and 3 a synthesis of characteristics of samples $A$ and $B$, respectively, is reported. Particularly, for sample A, a percentage of $32 \%$ had participated in previous evacuation trials; this percentage is equal to $63 \%$ for sample B and, for this sample, $61 \%$ of the total had a knowledge of risk field which was at least sufficient. In table 4, a synthesis of characteristics of joint sample $A+B$ is proposed. 
Table 2: $\quad$ Description of sample A.

\begin{tabular}{llrr}
\hline Data & & Value & Percentage \\
\hline Sex & Male & 13 & $52 \%$ \\
& Female & 12 & $48 \%$ \\
\hline Age & Average & 31,36 & \\
\hline Professional status & Workers & 25 & $100 \%$ \\
\hline Socio-economic data & Driving license owner & 23 & $92 \%$ \\
& Car owner & 19 & $76 \%$ \\
\hline Participation in evacuation trials & Yes & 8 & $32 \%$ \\
& No & 17 & $68 \%$ \\
\hline
\end{tabular}

Table 3: $\quad$ Description of sample B.

\begin{tabular}{llrr}
\hline Data & & Value & Percentage \\
\hline Sex & Male & 22 & $43 \%$ \\
& Female & 29 & $57 \%$ \\
\hline Age & Average & 21,02 & \\
\hline Professional status & Full Time Students & 49 & $96 \%$ \\
& Part Time Students & 2 & $4 \%$ \\
\hline Residence & Resident in Reggio Calabria & 29 & $57 \%$ \\
& Resident outside the province & 1 & $2 \%$ \\
& Resident inside the province & 21 & $41 \%$ \\
\hline Domicile & Domiciled in Reggio Calabria & 34 & $67 \%$ \\
\hline Socio-economic data & Driving license owner & 50 & $98 \%$ \\
& Car owner & 35 & $69 \%$ \\
& Motorvehicle owner & 17 & $33 \%$ \\
\hline Knowledge of risk issues & Good & 4 & $8 \%$ \\
& Sufficient & 27 & $53 \%$ \\
& Poor & 20 & $39 \%$ \\
\hline Participation in evacuation trials & Yes & 32 & $63 \%$ \\
& No & 19 & $37 \%$ \\
\hline
\end{tabular}

Table 4: $\quad$ Description of joint sample A+B.

\begin{tabular}{llrr}
\hline Data & & Value & Percentage \\
\hline Sex & Male & 42 & $55 \%$ \\
& Female & 34 & $45 \%$ \\
\hline Age & Average & 24,42 & \\
\hline Professional status & Full Time Students & 49 & $65 \%$ \\
& Part Time Students & 2 & $2 \%$ \\
& Worker & 25 & $33 \%$ \\
\hline Socio-economic data & Driving license owner & 73 & $96 \%$ \\
& Car owner & 54 & $71 \%$ \\
\hline Participation in evacuation trials & Yes & 8 & $11 \%$ \\
& No & 68 & $89 \%$ \\
\hline
\end{tabular}

\section{Specification, calibration and validation of proposed choice models}

In this section we propose different specifications with respect to the simulated scenarios $(1,2)$.

For all scenarios, we consider a behavioural approach, with random residual $\varepsilon_{\mathrm{j}}$ independently and identically distributed according to a Gumbel random variable of zero mean and parameter $\theta$. 
We consider a choice including two alternatives:

- to evacuate (e),

- $\quad$ not to evacuate (ne).

We define $V_{e}$ the systematic utility related to the alternative to evacuate and $V_{\text {ne }}$ the systematic utility related to the alternative not to evacuate.

A prototypal experimentation of a choice model simulating the choice to evacuate or not is proposed according to the logit model hypothesis.

It is important to highlight that SP surveys could be characterized by problems related to the realism in the responses of users and to the covariance among different scenarios. Other potential errors relate to: respondent fatigue, policy response bias, self-selectivity bias [7]. Recently, SP-off-RP questions have been introduced in choice modelling [15]. In particular, the alternatives and choice of a respondent in a real-world setting are observed, and the respondent is asked whether s/he would choose the same alternative or switch to another alternative if the attributes of the chosen alternative were less desirable in ways specified by the researcher and/or the attributes of non-chosen alternatives were more desirable in specified ways. This construction, called stated-preference off revealed-preference (SP-off-RP), is intended to increase the realism of the statedpreference task but creates endogeneity.

In this work we have considered standard SP surveys with their potential problems.

\section{$\underline{\text { Scenario } 1}$}

Sample $B$ and sample $A+B$

$$
\begin{gathered}
\mathrm{V}_{\mathrm{e}}=\beta_{\mathrm{DHI}} \cdot \mathrm{DHI}+\beta_{\mathrm{KR}} \cdot \mathrm{KR}+\beta_{\mathrm{TRAINING}} \cdot \text { TRAINING } \\
\mathrm{V}_{\mathrm{ne}}=\beta_{\mathrm{CAR}} \cdot \mathrm{CAR}+\beta_{\mathrm{RC}} \cdot \mathrm{RC}
\end{gathered}
$$

where

DHI is a dummy variable equal to 1 if the informer is the department head, to 0 otherwise;

$\mathrm{KR}$ is a variable related to knowhow in the risk field, in relation to higher education and/or career of the user and is specified as a dummy variable;

TRAINING is a variable equal to 1 if the users had already participated in evacuation trials, to 0 otherwise;

CAR is a variable equal to 1 if the user owns a car, to 0 otherwise;

$\mathrm{RC}$ is a variable equal to 1 if the user's home is in the town centre of Reggio Calabria, to 0 otherwise;

$\beta_{\mathrm{i}}$ are parameters to be calibrated, being i the linked attribute.

Obtained results from calibration are reported in table 5.

\section{$\underline{\text { Scenario } 2}$}

Sample B

$$
\begin{gathered}
\mathrm{V}_{\mathrm{e}}=\beta_{\mathrm{PI}} \cdot \mathrm{PI}+\beta_{\mathrm{Car}} \cdot \mathrm{Car}+\beta_{\mathrm{FTS}} \cdot \mathrm{FTS}+\beta_{\mathrm{KR}} \cdot \mathrm{KR} \\
\mathrm{V}_{\mathrm{ne}}=\beta_{\mathrm{MI}} \cdot \mathrm{MI}+\beta_{\mathrm{PM}} \cdot \mathrm{P}
\end{gathered}
$$


where

PI is a dummy variable equal to 1 if the informer is the professor, to 0 otherwise; CAR is a variable equal to 1 if the user owns a car, to 0 otherwise;

FTS is a dummy variable equal to 1 if the user is a full time student, to 0 otherwise;

$\mathrm{KR}$ is a variable related to knowhow in the risk field, in relation to higher education and/or career of the user and is specified as a dummy variable;

$\mathrm{MI}$ is a dummy variable equal to 1 if the informer is the Mayor, to 0 otherwise; $\mathrm{PM}$ is a variable equal to 1 if the user utilizes the motorcycle or car to go to school, to 0 otherwise;

$\beta$ are parameters to be calibrated.

Obtained results from calibration are reported in table 6.

Table 5: $\quad$ Parameter calibration for scenario 1.

\begin{tabular}{|c|c|c|c|c|c|}
\hline \multirow[b]{2}{*}{ Variable } & & \multirow[b]{2}{*}{ Alt. } & \multicolumn{2}{|c|}{ Sample B } & \multirow{2}{*}{$\begin{array}{c}\text { Sample A+B } \\
\text { Value } \\
\text { (t-student) }\end{array}$} \\
\hline & & & $\begin{array}{c}\text { Value } \\
\text { (t-student) }\end{array}$ & $\begin{array}{c}\text { Value } \\
\text { (t-student) }\end{array}$ & \\
\hline Department head informer & DHI & $\mathrm{e}$ & $\begin{array}{c}0,27 \\
(0,50)\end{array}$ & $\begin{array}{c}0,33 \\
(0,60)\end{array}$ & $\begin{array}{c}0,41 \\
(0,90)\end{array}$ \\
\hline Car ownership & CAR & ne & $\begin{array}{c}-0,17 \\
(-0,20)\end{array}$ & $\begin{array}{c}-0,42 \\
(-0,60)\end{array}$ & $\begin{array}{c}-1,75 \\
(-4,20)\end{array}$ \\
\hline Know how risk field & KR & e & $\begin{array}{c}0,60 \\
(0,90)\end{array}$ & & \\
\hline Home in Reggio Cal. & RC & ne & $\begin{array}{c}-1,38 \\
(-2,30)\end{array}$ & $\begin{array}{c}-1,50 \\
(-2,50)\end{array}$ & \\
\hline Participation at evacuation trials & TRAINING & e & $\begin{array}{c}1,18 \\
(1,90)\end{array}$ & $\begin{array}{c}1,23 \\
(2,20)\end{array}$ & $\begin{array}{c}1,55 \\
(3,00)\end{array}$ \\
\hline Num. obs. & & & 102,00 & 102,00 & 152,00 \\
\hline Initial value & & & $-70,70$ & $-70,70$ & $-105,36$ \\
\hline Final value & & & $-33,87$ & $-34,28$ & $-50,72$ \\
\hline rho-quadro & & & 0,52 & 0,52 & 0,52 \\
\hline
\end{tabular}

Table 6: $\quad$ Parameter calibration for scenario 2 (sample B).

\begin{tabular}{|c|c|c|c|c|}
\hline Variable & & Alt. & $\begin{array}{c}\text { Value } \\
\text { (t-student) }\end{array}$ & $\begin{array}{c}\text { Value } \\
\text { (t-student) }\end{array}$ \\
\hline Professor informer & PI & $\mathrm{e}$ & $\begin{array}{c}1,18 \\
(2,20)\end{array}$ & $\begin{array}{c}1,16 \\
(2,10)\end{array}$ \\
\hline Mayor informer & MI & e & $\begin{array}{c}+0,68 \\
(+1,40)\end{array}$ & $\begin{array}{l}-0,66 \\
(1,40)\end{array}$ \\
\hline Car ownership & CAR & e & $\begin{array}{c}0,65 \\
(1,40)\end{array}$ & $\begin{array}{c}0,59 \\
(1,23)\end{array}$ \\
\hline Full time student & FTS & e & $\begin{array}{c}1,23 \\
(2,90)\end{array}$ & $\begin{array}{c}1,16 \\
(2,60)\end{array}$ \\
\hline Risk know how & KR & e & $\begin{array}{c}-1,06 \\
(-2,20)\end{array}$ & $\begin{array}{l}-1,02 \\
(2,01)\end{array}$ \\
\hline Private mode & PM & ne & & $\begin{array}{c}-0,32 \\
(-0,70) \\
\end{array}$ \\
\hline $\begin{array}{l}\text { Num. obs. } \\
\text { Initial value } \\
\text { Final value } \\
\text { rho-quadro }\end{array}$ & & & $\begin{array}{c}153,00 \\
-106,05 \\
-68,96 \\
0,35\end{array}$ & $\begin{array}{c}153,00 \\
-106,05 \\
-68,74 \\
0,35\end{array}$ \\
\hline
\end{tabular}


Sample $A+B$

$$
\begin{gathered}
\mathrm{V}_{\mathrm{e}}=\beta_{\mathrm{PI}} \cdot \mathrm{PI}+\beta_{\mathrm{DL}} \cdot \mathrm{DL}+\beta_{\mathrm{FTS}} \cdot \mathrm{FTS}+\beta_{\mathrm{MI}} \cdot \mathrm{MI} \\
\mathrm{V}_{\mathrm{ne}}=\beta_{\mathrm{SI}} \cdot \mathrm{SI}+\beta_{\mathrm{TRAINING}} \cdot \text { TRAINING }
\end{gathered}
$$

where

PI is a dummy variable equal to 1 if the informer is the professor, to 0 otherwise; $\mathrm{DL}$ is a variable equal to 1 if the user owns the driving license, to 0 otherwise; FTS is a dummy variable equal to 1 if the user is a full time student, to 0 otherwise;

MI is a dummy variable equal to 1 if the informer is the Mayor, to 0 otherwise; TRAINING is a variable equal to 1 if the user has already participated in evacuation trials, to 0 otherwise;

SI is a dummy variable equal to 1 if the informer is the stranger, to 0 otherwise; $\beta$ are parameters to be calibrated.

Obtained results from calibration are reported in table 7.

Proposed models were validated by verifying the reasonableness and the significance of estimated coefficients, as well as the model's ability to reproduce the choices made by a sample of users. All these activities can be completed with appropriate tests of hypotheses for a sample of users. In this work, we performed informal and formal tests. Informal tests are based on the expectations on the signs of the coefficient calibrated. Formal tests allow us to verify different assumptions on Maximum Likelihood estimates using asymptotic results. The t-student statistic allows us to verify that all the estimates of the coefficient are significantly different from zero. The rhosquare allow the model's goodness of fit to be ascertained, i.e. its ability to reproduce the choices made by a sample of users.

\begin{tabular}{|c|c|c|c|c|c|}
\hline Variable & & Alt. & $\begin{array}{c}\text { Value } \\
\text { (t-student) }\end{array}$ & $\begin{array}{c}\text { Value } \\
\text { (t-student) }\end{array}$ & $\begin{array}{c}\text { Value } \\
\text { (t-student) }\end{array}$ \\
\hline Professor informer & PI & $\mathrm{e}$ & $\begin{array}{c}0,96 \\
(1,80)\end{array}$ & $\begin{array}{c}0,66 \\
(1,20)\end{array}$ & $\begin{array}{c}0,64 \\
(1,20)\end{array}$ \\
\hline Mayor informer & MI & $\mathrm{e}$ & $\begin{array}{c}+0,48 \\
(+1,00)\end{array}$ & & \\
\hline Stranger informer & SI & ne & & $\begin{array}{c}0,19 \\
(0,40)\end{array}$ & $\begin{array}{c}0,20 \\
(0,40)\end{array}$ \\
\hline Driving license & DL & e & $\begin{array}{c}+0,99 \\
(+2,50)\end{array}$ & $\begin{array}{c}1,40 \\
(4,10)\end{array}$ & $\begin{array}{c}1,22 \\
(1,50)\end{array}$ \\
\hline Participation at evacuation trials & Training & ne & $\begin{array}{c}-0,15 \\
(-0,40)\end{array}$ & & \\
\hline Full Time Student & FTS & e & & & $\begin{array}{c}0,20 \\
(0,20) \\
\end{array}$ \\
\hline Num. obs. & & & 153,00 & 153,00 & 153,00 \\
\hline Initial value & & & $-106,05$ & $-106,05$ & $-106,05$ \\
\hline Final value & & & $-71,01$ & $-71,30$ & $-71,30$ \\
\hline rho-quadro & & & 0,33 & 0,33 & 0,33 \\
\hline
\end{tabular}

Table 7: $\quad$ Parameter calibration for scenario 2 (Sample A+B). 


\section{Conclusion}

In this paper we have proposed the specification, calibration and validation of demand models able to simulate the choice of a generic user to evacuate or not in emergency conditions, starting from SP data. We have considered two scenarios, defined considering an anthropogenic kind of dangerous event, delayed effect in the time of the dangerous event and absence of constrained times to evacuate.

The scenarios differ in respect of:

- $\quad$ effect in the space, that is punctiform for scenario 1 and diffused for scenario 2;

- $\quad$ place of effect for users during the dangerous event, that is the user's workplace for scenario 1 and downtown, for scenario 2;

- considered informer

o stranger or department head, for scenario 1;

o stranger, representative of the Mayor, professor, for scenario 2.

Obtained results confirm the role of the informer highlighted in previous papers, based on the statistical analysis of stated preferences data [8, 9]. In particular, this paper shows that higher evacuation percentages are obtained if the informer is the department head or the professor.

Calibrated parameters confirm this result. In fact, for scenario 1, the parameter associated to the head of the department informer is positive and represents the trend to evacuate for every considered specification (Sample B, Sample A+B). In scenario 2, it is possible to compare the obtained parameter for three different types of informer. Other results show that:

- for the professor, the calibrated parameter represents the trend to evacuate and is higher, in comparison with the parameter associated to a representative of the Mayor and stranger;

- for the representative of the Mayor, the calibrated parameter is positive and represents the trend to evacuate, even if the value is lower in comparison with that associated to the professor;

- $\quad$ for the stranger, the calibrated parameter is positive, but it is specified in the alternative not to evacuate, then it represents the trend to not evacuate.

A prototypal result is related to the variable training, specified for scenario 1. This is characterized by a positive sign and then represents the trend to evacuate; moreover, the obtained t-student is very high, for every specification (Sample B, Sample $A+B$ ), as training is very significant in the user's choices. These results support psychological studies related to the human behaviour in emergency conditions.

Finally, the trend to evacuate is, moreover, related to car ownership, driving license and the user's home is in the town centre of Reggio Calabria.

Our next objectives are finalized to analyze, in a more in depth approach, the influence of training in the user's choices and to develop a comparison between SP and SP-off-RP approaches. 


\section{References}

[1] Russo F. and Chilà G., Safety of users in road evacuation: demand models. WIT Transactions on the Built Environment, Volume 96, Urban Transport XIII, Urban Transport and the Environment in the 21st century, Brebbia C. A. (ed.), WIT Press, Southampton, pp. 773-782, 2007.

[2] Russo F. and Vitetta A., Risk evaluation in a transportation system. International Journal of Sustainable Development and Planning, 1 (2), pp. 170-191, 2006.

[3] Wilmot C.G. \& Fu H., A sequential logit dynamic travel demand model for hurricane evacuation. Transp. Research Record, 1882, pp. 19-26, 2004.

[4] Cheng, G., Wilmot C.G., and Baker R.J., A destination choice model for hurricane evacuation. In Transp. Research Board Annual Meeting 2008. CD-ROM. Washington, D.C., 2008.

[5] Hasan, S., Hukkussuri, S., Murray-Tuite, P., A Behavioral Model to Understand Household Level Hurricane Evacuation Decision Making. Submitted for Publication in ASCE Journal of Transportation, 2011.

[6] Russo F. and Chilà G., Safety of users in road evacuation: RP vs. SP surveys in demand analysis. WIT Transactions on the Built Environment, Volume 101, Urban Transport XIV, Urban Transport and the Environment in the 21st century, Brebbia C. A. (ed.), WIT Press, Southampton, pp. 703713, 2008.

[7] Ortuzar, J. and de D. Willumsen, L.G., Modelling Transport, John Wiley \& Sons Ltd, Chichester, 2006.

[8] Russo F. and Chilà G., A statistical approach to analyse user behaviour in road evacuation. WIT Transactions on the Built Environment, Volume 117, Safety and Security engineering IV, Guarascio M., Reiners G. Brebbia C. A. and Garzia F. (ed.), WIT Press, Southampton, pp. 377-390, 2011.

[9] Russo F. and Chilà G., Models in road evacuation: role of the informer in user behaviour. Proceedings of Sustainable City 2012, 7th International Conference on Urban Regeneration and Sustainability, Brebbia C. A. (ed.), WIT Press, Southampton, 2012.

[10] Russo, F. and Rindone, C., Safety of users in road evacuation: Modelling and DSS for LFA in the planning process. WIT Transactions on Ecology and the Environment, 120, pp. 453-464, 2009.

[11] Russo, F. and Rindone, C., Safety of users in road evacuation: Planning internal processes and guidelines. WIT Transactions on the Built Environment, 96, pp. 825-834, 2007.

[12] Vitetta, A., Musolino, G. and Marcianò, F.A., Safety of users in road evacuation: Supply and demand-supply interaction models for users. WIT Transactions on the Built Environment, 96, pp. 783-792, 2007.

[13] Polimeni, A. and Vitetta, A., Optimising waiting at nodes in timedependent networks: cost functions and applications. Journal of Optimization Theory and Applications, 156(3), pp. 805-818, 2013. 
752 Sustainable Development and Planning VI

[14] Polimeni A. and Vitetta A., Dynamic vehicle routing in road evacuation: Route design experimentation, WIT Transactions on the Built Environment, 117, pp. 391-402, 2011.

[15] Train K. and Wilson W.W., Monte Carlo analysis of SP-off-RP data. Journal of Choice Modelling, 2(1), pp. 101-117, 2009. 